\title{
PERTIMBANGAN HAKIM TERHADAP PENYALAHGUNAAN \\ KEADAAN (MISBRUIK VAN OMSTANDIGHEDEN) DALAM PERJANJIAN KREDIT BANK (Studi Kasus Terhadap Putusan Mahkamah Agung Nomor 2039 K/Pdt/2014)
}

\author{
${ }^{1}$ Rifqi Fadillah, ${ }^{2}$ Faisal, ${ }^{2}$ Fatahillah \\ Co Author e-mail : faisal@unimal.ac.id \\ ${ }^{1}$ Mahasiswa Fakultas Hukum Universitas Malikussaleh \\ ${ }^{2}$ Dosen Fakultas Hukum Universitas Malikussaleh
}

Abstrak

Penyalahgunaan keadaan dalam hukum perdata di Indonesia merupakan hal yang baru, namun dalam praktek dilapangan telah diterapkan sampai pada tingkat peradilan, walaupun dalam berbagai putusan hakim secara tegas menyatakan bahwa suatu perjanjian didasarkan pada alasan adanya keadaan, tetapi karena adanya Kurang kepatutan dalam perjanjian, menyebabkan timbulnya penyalahgunaan keadaan karena posisi tawar pihak lain yang tidak setara. Penelitian ini bertujuan untuk mengetahui pengaturan dalam hukum positif Indonesia terhadap penyalahgunaan keadaan dalam perjanjian kredit bank, serta untuk mengetahui pertimbangan hakim pada Pengadilan Negeri Kelas I B Lhokseumawe terhadap penyalahgunaan keadaan dalam perjanjian kredit bank. Penelitian ini menggunakan jenis penelitian yuridis normatif, yaitu dengan mengkaji permasalahanpermasalahan yang muncul dari segi hukum dan sebenarnya berasal dari peraturan perundang-undangan yang berlaku, dengan menggunakan pendekatan penelitian kualitatif. Adapun teknik pengumpulan data dilakukan melalui penelitian lapangan (field research) dan penelitian kepustakaan (Library Research). Berdasarkan hasil penelitian diketahui bahwa, Ajaran penyalahgunaan keadaaan memang belum diatur secara eksplisit di dalam KUHPerdata. Namun ajaran penyalahgunaan keadaan di Indonesia ini berkembang dan didukung oleh beberapa putusan hakim. Pertimbangan hakim pada Pengadilan Negeri Kelas I B Lhokseumawe terhadap penyalahgunaan keadaan dalam perjanjian kredit bank, majelis hakim merujuk kepada beberapa sumber hukum peraturan perundang-undangan dan yurisprudensi adapun tolak ukur yang digunakan oleh hakim dalam menentukan adanya penyalahgunaan keadaan ini, yaitu penyalahgunaan keunggulan ekonomis dan penyalahgunaan keunggulan kejiwaan dalam hal menyelesaikan perkara penyalahgunaan keadaan. Disarankan kepada para akademisi hukum agar kiranya terus mengkaji mengembangkan konsep penyalahgunaan keadaan ini agar dapat lebih diterapkan dengan efektif. Begitu juga kepada lembaga penegak hukum untuk lebih progresif dalam menangani masyarakat yang terjebak dalam perjanjian yang mengandung unsur penyalahgunaan keadaan.

Katakunci: Penyalahgunaan Keadaan, KUHPerdata, perjanjian, 


\section{PENDAHULUAN}

Sejak tiga dekade terakhir telah dikenal istilah penyalahgunaan keadaan (misbruik van omstandigheden). Penyalahgunaan keadaan atau misbruik van omstandigheden adalah perbuatan yang dilakukan terhadap pihak lain yang terikat dalam suatu perjanjian dengan memanfaatkan kedudukan yang tidak setara dari salah satu pihak dengan tujuan untuk mengambil keuntungan ekonomis saja. ${ }^{1}$ Keadaan yang tidak keseimbangan ini dapat berupa paksaan, kurangnya pertimbangan atau ketergantungan satu pihak terhadap pihak lain.

Meskipun penyalahgunaan keadaan belum tercantum dalam KUHPerdata sebagai salah satu alasan untuk membatalkan suatu perjanjian, namun dalam praktek dilapangan telah diterapkan sampai pada tingkat peradilan, walaupun dalam beberapa putusan pengadilan secara tegas menyatakan bahwa suatu perjanjian didasarkan pada alasan adanya keadaan, ${ }^{2}$ tetapi karena adanya Kurang kepatutan dalam perjanjian, menyebabkan timbulnya penyalahgunaan keadaan karena posisi tawar pihak lain yang tidak setara.

Penyalahgunaan keadaan sering terjadi pada perbuatan suatu perjanjian kredit antara kreditur dan debitur. Posisi debitur sering kali terabaikan dan kedudukan debitur selalu terpojokkan, sehingga dalam keadaan yang mendesak, debitur tidak memiliki posisi tawar yang cukup kuat sehingga perjanjian kredit dalam prakteknya selalu mendekati konsep perjanjian baku, dimana semua isi kredit dan klausul-klausul di dalamnya selalu menguntungkan si kreditur karena isi klausula ditentukan sendiri oleh kreditur itu juga.

Salah satu contoh kasus yang menerapkan doktrin penyalahgunaan keadaan tersebut, dapat dilihat pada sengketa Nomor Putusan 2039 K/Pdt/2014. dari kasus tersebut yang telah diputuskan pada tahun 2014, terdapat alasan dalil penyalahgunaan keadaan (misbruik van omstandigheiden).

Putusan tersebut membuktikan bahwa penyalahgunaan keadaan telah digunakan dan dijadikan dasar dalam praktik praktik peradilan. Namun disisi lain penerapan doktrin ini dikalangan para ahli masih menjadi perdebatan, apakah doktrin ini telah diterima di pengadilan dan apa yang menjadi penilaian pertimbangan keadaan tersebut.

\section{METODE PENELITIAN}

Jenis penelitian yang digunakan dalam penelitian ini adalah jenis yuridis normatif, dengan mengkaji permasalahan-permasalahan yang muncul dari segi hukum dan sebenarnya berasal dari peraturan perundang-undangan yang berlaku, teori-teori hukum dan pandangan-pandangan hukum sebagai dasar acuan. ${ }^{3}$

Metode pendekatan dalam Penelitian ini menggunakan pendekatan kualitatif, yaitu pendekatan penelitian yang menggunakan data berupa kalimat tertulis atau lisan, pristiwaperistiwa, pengetahuan atau objek studi ${ }^{4}$.

Penelitian ini bersifat deskriptif yaitu penelitian yang bertujuan untuk menghasilkan data yang bersifat deskriptif analitis yaitu metode yang dipakai untuk menggambarkan suatu kondisi atau keadaan yang sedang berlangsung yang kemudian

\footnotetext{
${ }^{1}$ Haris hamid, Hukum Perlindungan Konsumen, Sah Media, Makassar, 2017, hlm. 90.

${ }^{2}$ Endro Martono.2016 Penyalahgunaan Keadaan Sebagai Dasar Pembatalan Perjanjian. Jurnal Yustisia Merdeka: Jurnal Ilmiah Hukum. Volume 2 Nomor 2, hal. 9.

${ }^{3}$ Lexy J. Moleong, Penelitian Kualitatif, Remaja Rosdakarya, Jakarta, 2007, hlm. 9.

${ }^{4}$ Amiruddin, Pengantar Metode Penelitian Hukum, Raja Grapindo Persada, Jakarta, 2012, hlm. 7 .
} 
dianalisis berdasarkan perundang-undangan yang berlaku. ${ }^{5}$ Pada penelitian ini menjelaskan mengenai pertimbangan hakim terhadap penyalahgunaan keadaan (misbruik van omstandigheden) dalam perjanjian kredit bank terkait Putusan Nomor 2039 $\mathrm{K} / \mathrm{Pdt} / 2014$.

\section{HASIL PENELITIAN DAN PEMBAHASAN}

\section{Penyalahgunaan Keadaan dalam Perjanjian Kredit Bank}

\section{a. Ajaran Penyalahgunaan Keadaan}

Sebelum penyalahgunaan keadaan dicantumkan kedalam NBW, banyak isu yang terkandung di dalamnya yang dibahas oleh para ilmuwan, terutama terkait dengan putusan perkara oleh hakim. Sebagaimana dijelaskan oleh Henry P Panggabean "Bukan secara kebetulan bahwa Ferdinand Jacobus Domela Nieuwenhuis selalu mengkaitkan pembahasannya dengan arresten yang dijumpai di Nederland. Dimasukkannya situasi tersebut ke dalam NBW merupakan sedikit banyaknya hasil dari pertimbangan hukum dalam putusan hakim."

Penyalahgunaan keadaan mengenai syarat-syarat yang berlaku dalam terjadinya suatu kontrak atau perjanjian, tidak menyebabkan batalnya isi kontrak atau maksudnya, tetapi menyebabkan kehendak yang disalah gunakan. ${ }^{7}$ Sebagai contoh, hakim sering menemukan situasi yang bertentangan dengan adat, sehingga seringkali mengakibatkan pertimbangan hakim dalam membuat putusan atas suatu kesepakatan.

Namun, pada waktu itu belum juga diatur ketentuannya di dalam Burgerlijk Wetboek. Sehingga terbentuknya ajaran penyalahgunaan keadaan tersebut disebabkan karena banyaknya permasalahan yang dibahas oleh para ahli hukum dan ilmuwan lainnya, terkait dengan pemutusan perkara oleh para hakim. Sehingga ketentuan penyalahgunaan keadaan tersebut dicantumkan dalam Neuw Burgerlijk Wetboek yang selanjutnya disebut NBW193.

Berdasarkan hal tersebut diketahui bahwa pertimbangan hakim tidak hanya berdasarkan pada salah satu alasan pembatalan perjanjian, yaitu cacat kehendak klasik yang berupa kesesatan, paksaan, dan tipu daya, sehingga dibuat kesimpulannya dalam Pasal 1321 BW hanya ada kesesatan, paksaan, dan penipuan, tetapi dalam NBW diatur bahwa dalil cacat kehendak dapat didasarkan pada kesesatan, paksaan, penipuan, dan keadaan.

Van Dunne mengemukakan pendapat bahwasanya berhubungan dengan terjadinya kontrak. Penyalahgunaan keadaan mengenai keadaan yang berperan saat terjadinya kontrak, seperti memanfaatkan keadaan orang lain tidak menyebabkan isi kontrak atau maksudnya tidak diizinkan, tetapi menyebabkan disalahgunakan kehendak. ${ }^{8}$

Ajaran penyalahgunaan keadaan sendiri mengandung dua unsur, yaitu unsur penyalahgunaan keadaan (kesempatan) oleh pihak lain dan unsur kerugian bagi satu

\footnotetext{
${ }^{5}$ Zainuddin Ali, Metode Penelitian Hukum, Sinar Grafika, Jakarta, 2009, hlm. 223.

${ }^{6}$ Henry P Panggabean, Op. Cit., hlm. 41.

${ }^{7}$ Van Dunne,Diktat Kursus Hukum Perikatan yang diterjemahkan Sudikno Mertokusumo, Yogyakarta, 1987, hlm. 9.

8 Fatmah Paparang, Misbruik Van Omstandigheden Dalam Perkembangan Hukum Kontrak, Jurnal Fakultas Hukum Universitas Sam Ratulangi, Sulawesi Utara, Vol. 22, No. 6, Juli 2016.
} 
pihak. Kedua unsur tersebut yaitu keuntungan keunggulan ekonomi dan keuntungan psikologis, yang diuraikan sebagai berikut: ${ }^{9}$

1. Persyaratan-persyaratan untuk penyalahgunaan keunggulan ekonomis, yaitu:

a. Satu pihak mempunyai keuntungan keunggulan ekonomi terhadap pihak yang lain

b. Pihak yang lain terpaksa dalam mengadakan perjanjian

2. Persyaratan untuk adanya penyalahgunaan keunggulan jiwa:

a. Salah satu pihak memiliki hubungan khusus, seperti hubungan kepercayaan antara keluarga, suami istri, dokter dan pasien, dan lain-lain..

b. Salah satu pihak menggunakan kondisi mental khusus pihak lainnya, seperti kondisi gangguan jiwa, kurangnya pengalaman, kecerobohan, kurangnya pengetahuan, kondisi fisik yang buruk, dan sebagainya.

\section{b. Penyalahgunaan Keadaan Dalam Perjanjian Kredit Bank}

Saat ini dapat diketahui bahwa kontrak menjadi instrumen yang penting dalam kegiatan bisnis karena dapat berfungsi memberikan kepastian dan keamanan dalam transaksi bisnis. Sehingga kontrak diketahui sudah berada didalam ditengah-tengah masyarakat dimana melakukan kontrak adalah kegiatan hukum yang sehari-hari dilakukan masyarakat. Dalam melakukan kontrak memiliki tujuan yang sama dari para pihak yaitu tercapainya kata sepakat. Untuk mencapai kata sepakat ini akan memiliki proses negoisasi terlebih dahulu untuk menyatukan kepentingan para pihak yang akan tercapainya kata sepakat. Akan tetapi ketika sudah mencapai kata sepakat terkadang adanya unsur kekhilafan, paksaan ataupun penipuan.

Kesepakatan tersebut dapat dikatakan sebagai kesepakatan terpaksa (contradiction in interminis) atau unsur yang mengandung cacat kesepakatan. Sebagaimana ketentuan yang mengatur terkait keabsahan perjanjian bahwa, kesepakatan itu dianggap tidak sah apabila kesepakatan itu dibentuk karena kekhilafan, paksaan atau penipuan. ${ }^{10}$ Konsekuensi dari kesepakatan di dalam kontrak yang mengandung unsur cacat kehendak adalah kontrak tersebut dapat dimintakan pembatalan.

Ketentuan pasal 1321 dan pasal 1449 KUHPerdata menegaskan bahwa cacat kesepakatan atau cacat kehendak itu terjadi karena kekhilafan/kesesatan, penipuan dan paksaan. Penyalahgunaan keadaan sebagai salah satu syarat cacat kehendak berkembang oleh karena perkembangan beberapa peristiwa hukum dalam hukum kontrak. Penyalahgunaan keadaan terjadi apabila seseorang mengetahui atau seharusnya mengerti bahwa pihak lain dikarena suatu keadaan khusus seperti keadaan darurat, ketergantungan, tidak dapat berfikir panjang, keadaan jiwa yang abnormal atau tidak berpengalaman tergerak untuk melakukan suatu pebuatan hukum meskipun seseorang tersebut mengetahui atau seharusnya mengerti sebenarnya ia harus mencegahnya. ${ }^{11}$

Memperhatikan ketentuan didalam KUHPerdata tersebut, bahwasanya dapat diketahui asas kebebasan berkontrak tidak bermakna bebas mutlak karena adanya pembatasan yang terdapat dibeberapa pasal. Asas konsensualitas yang terdapat didalam

9 Henry P. Panggabean, Penyalahgunaan Keadaan (Misbruik Van Omstandigeden Sebagai Alasan Baru) Untuk Pembatalan perjanjian (Berbagai perkembangan Hukum di Belanda), cet.1, Liberty, Yogyakarta, 2001, hlm. 44.

${ }^{10}$ Lihat Pasal 1321 KUHPerdata. 2010, hlm. 5 .

${ }^{11}$ Ahmad Miru, Hukum Kontrak dan Perancangan Kontrak, Rajawali Press, Jakarta, 
pasal 1320 ayat (1) KUHPerdata menentukan bahwa suatu perjanjian atau kontrak tidak sah jika dibuat tanpa persetujuan atau kesepakatan para pihak yang membuatnya. Artinya kebebasan salah satu pihak untuk menentukan isi perjanjian diatur oleh ketentuan pihak lain. Dengan kata lain asas kebebasan berkontrak dibatasi oleh ketentuan kesepakatan para pihak. Adapun didalam pasal 1321 KUHperdata mempertegas kembali bahwasanya tiada kebebasan dalam perjumpaan kehendak atau consensus yang diberikan karena khilaf, paksaan atau penipuan yang berakibat kontrak menjadi tidak sah. Begitu pula dengan terdapatnya asas itikad baik yang terdapat didalam pasal 1338 ayat (3) KUHPerdata yang merupakan pembatasan terhadap berlakunya asas kebebasan berkontrak. Kebebasan para pihak dalam melakukan kontrak tidak dapat dilakukan dengan kehendaknya saja akan tetapi harus memiliki itikad baik.

Ajaran penyalahgunaan keadaaan memang belum diatur secara eksplisit di dalam KUHPerdata. Meskipun demikian secara praktik yurisprudensi, peyalahgunaan keadaan pernah dijadikan alasan untuk membatalkan suatu perjanjian. Ajaran tentang situasi penyalahgunaan keadaan di Indonesia berkembang dan didukung oleh putusan hakim pada pengadilan. Pada prinsipnya putusan hakim tersebut menyatakan bahwa kontrak yang lahir dari pernyataan kehendak para pihak, apabila dipengaruhi penyalahgunaan keadaan maka merupakan unsur cacat kehendak dalam pembentukan kontrak. ${ }^{12}$

\section{c. Penyalahgunaan Keadaan Dalam Hukum Positif Indonesia}

Salah satu pengaturan dalam KUHPerdata belum dicabut adalah buku ke III KUHPerdata tentang perikatan. Hukum perikatan di Indonesia masi sangat kental mengikuti hukum peninggalan Belanda dari dulu hingga sekarang. Belanda melakukan perkembangan hukum perjanjiannya salah satunya dalam hal sebab batalnya perjanjian yaitu memasukkan penyalahgunaan keadaan (misbruik van de omstandigheden) sebagai salah satu sebab batalnya perjanjian/kontrak selain dari kesesatan, ancaman maupun penipuan. Penyalahgunaan keadaan ini merupakan doktrin yang justru akan berasal dari civil law, seperti hukum Belanda yang masi dipakai Indonesia sampai saat ini.

Pada abad ke-20, muncul berbagai kritik dan alasan kebebasan berkontrak, baik terkait dengan akibat negatif yang ditimbulkannya, maupun pemikiran yang melekat di dalamnya. Paradigma kebebasan berkontrak berkembang menuju paradigma kepatutan. Meskipun kebebasan berkontrak masih penting dalam hukum kontrak, maupun dalam sistem hukum. Namun, tampaknya kebebasan berkontrak tidak lagi berkembang pada abad ke-19. Oleh karena itu, negara menjalankan kebebasan berkontrak yaitu, Pertama, makin berpengaruhnya ajaran itikad baik, dimana itikad baik bukan saja pada saat pelaksaan perjanjian, tetapi harus sudah ada pada tahap pembuatan perjanjian. Kedua, makin berkembangnya ajaran penyalahgunaan keadaan (misbruik van de omstandigheden).

Walaupun ajaran penyalahgunaan keadaan tidak diatur dalam KUHPerdata namun telah dikenal cukup luas dalam khasanah hukum di Indonesia. Dimana telah banyak hakim di Indonesia dalam memutus perkara dalam pengadilan menggunakan alasan penyalahgunaan keadaan yang kemudian menjadi yurisprudensi dan diadopsi kedalam

\footnotetext{
${ }^{12}$ Lihat selengkapnya dalam kasus Luhur Sundoro/Ny. Oei Kwie Lian c.s sebagaimana telah diputus oleh Mahkamah Agung RI No. 1904 K/Sip/1982 dan pada kasus Sri Setyaningsih/Ny. Boesono c.s sebagaimana telah diputus oleh Mahkamah Agung No. 3431 K/Sip/1985.
} 
penyalahgunaan keadaan dalam hukum perjanjian di Indonesia sebagai alasan hakim untuk membatalkan perjanjian atau kontrak di pengadilan adalah sebagai akibat dari amanat Undang-Undang Nomor 48 tahun 2009 tentang Kekuasaan Kehakiman yaitu terdapat dalam pasal 10 ayat (1) yang berbunyi:

"Pengadilan dilarang menolak untuk memeriksa, mengadili, dan memutus suatu perkara yang duajukan dengan dalih bahwa hukum tidak ada atau kurang jelas, melainkan wajib untuk memeriksa dan mengadilinya".

Dalam pasal tersebut dapat diketahui bahwa hakim tidak hanya menerapkan yang sudah diatur didalam Undang-Undang, tetapi hakim dalam memeriksa, mengadili dan memutus perkara di pengadilan juga harus melakukan penemuan hukum dan penafsiran hukum. Hakim dalam mengadili suatu perkara harus terlebih dahulu mengetahui benar atau tidaknya peristiwa yang dihadirkan kepadanya. Setelah berhasil menentukan acara, hakim kemudian harus memenuhi persyaratan acara. Setelah itu hakim harus menentukan hukum apa yang digunakan untuk menyelesaikan sengketa yang bersangkutan. Di sini kemudian hakim harus menentukan. Hakim di Indonesia dalam menentukan hukum ini merujuk kepada beberapa sumber hukum peraturan perundang-undangan dan yurisprudensi, namun tidak terikat pada yurisprudensi atau putusan hakim yang terdahulu menjadi pertimbangan hukum bagi hakim selanjutnya. ${ }^{13}$

Menurut Utiyafina Mardhati Hazhin, beberapa tolak ukur yang digunakan oleh hakim dalam menentukan adanya penyalahgunaan keadaan ini ${ }^{14}$.

1. Tolok ukur moral yang meliputi kepatutan dan keadilan. Harta benda dan keadilan dijadikan tolak ukur oleh hakim dalam menentukan kondisi kedua belah pihak, hal ini sebagai bentuk pertimbangan yang melihat keuntungan ekonomis dan psikologis kreditur, sehingga apakah menghasilkan posisi tawar yang seimbang antara kedua belah pihak.

2. Tolok ukur itikad baik. Hakim menggunakan tolok ukur itikad baik sebagai bentuk awal keadaan, hal ini terlihat ketika hakim menganggap kreditur tidak memberikan kredit kepada debitur.

3. Tolak ukur keuntungan. Patokan keuntungan yang digunakan oleh hakim juga berkaitan dengan itikad baik, yaitu ketika seorang kreditur memberikan kredit dengan maksud tetapi ternyata dia hanya ingin meningkatkan keuntungan dengan meningkatkan kredit dalam waktu singkat, yang kemudian bertentangan dengan kepatutan dan hukum.

Niewenhuis yang menyebutkan tentang dua aspek penting untuk mengetahui sifat serta luasnya hak dan kewajiban dari hubungan kontraktual, yaitu: ${ }^{15}$

1. Interprestasi (penafsiran) terhadap sifat serta luasnya hak dan kewajiban kontraktual

2. Faktor-faktor yang berpengaruh terhadap sifat serta luasnya hak dan kewajiban kontraktual, meliputi:

a. Faktor otonom (terkait daya mengikatnya kontrak).

13 Enrico Simanjuntak, Peran Yurisprudensi dalam Sistem Hukum Indonesia, Jurnal Fakultas Hukum Universitas Indonesia, Jakarta, Vol. 16, No. 1, Maret 2019.

${ }^{14}$ Utiyafina Mardhati Hazhin, Penyalahgunaan Keadaan dalam Perjanjian Asuransi dalam Telemarketing, Jurnal Fakultas Hukum Universitas Surabaya, Surabaya, Vol. 41, No. 2, Agustus 2019.

${ }^{15}$ Siti Malikhatun Badriyah, Sistem Penemuan Hukum dalam Masyarakat Prismatik, Sinar Grafika, Jakarta, 2016, hlm. 123. 
b. Faktor heteronom (faktor-faktor yang berasal dari luar para pihak), terdiri dari: Undang-Undang, kebiasaan (gebruik), syarat yang biasa diperjanjikan (bestandig gebruikelijk beding), kepatutan (billijkheid), dan keadilan.

Dalam permasalahan ini hakim sudah mempertimbangkan faktor dalam menentukan adanya penyalahgunaan dengan mempertimbangkan dari aspek kepatutan dan keadilan pihak yang lemah.

Perkembangan hukurn khususnya dalam praktek peradilan di Indonesia adanya penyalahgunaan keadaan dapat dijadikan alasan untuk membatalkan suatu pejanjian, meskipun hal ini secara tegas tidak diatur dalam KLTHPerdata, khususnya dalam pasalpasal yang menyebutkan tentang alasan-alasan kebatalan yaitu 1322 tentang kekhilafan, pasal 1323 tentang paksaan dan pasal 1328 tentang penipuan, sebagai alasan pembatalan perjanjian.

Pada hakikatnya penyalahgunaan keadaan tidak hanya terkait dengan isi perjanjian yang tidak seimbang. namun juga perjanjian yang dianggap bertentangan dengan kesusilaan atas dasar yang menyertai terjadinya perjanjian. Jadi masalahnya bukanlah "sebab/sebab" yang dilarang, tetapi kehendak yang salah, cara untuk "memaksa" perjanjian yang "disalahgunakan"..

Beberapa hal yang diketemukan dalam suatu kasus yang berhubungan dengan penyalahgunaan keadaan antara lain dapat dilihat dalam perkara perdata antara Muhammad Nasir sebagai pemohon kasasi dahulu penggugat / pembanding melawan PT. Bank Pundi Indonesia Tbk, sebagai Termohon kasasi dahulu tergugat/ terbanding, sebagaimana tertuang dalam sengketa perjanjian pada Pengadilan Negeri Kelas IB Lhokseumawe, Nomor Putusan 2039 K/Pdt/2014

Perkara yang ditangani oleh Pengadilan Negeri Kelas I B Lhokseumawe Nomor Putusan 2039 K/Pdt/2014 antara penggugat dan tergugat dimana duduk perkara dalam putusan tersebut, bahwa Pemohon Kasasi yang dahulu sebagai Penggugat/ Pembanding di muka persidangan Pengadilan Negeri Kelas IB Lhokseumawe menggugat PT. Bank Pundi Indonesia, Tbk Cabang Lhokseumawe, menyebutkan penggugat memiliki usaha grosir sayur yang berlokasi pasar Inpres Kota Lhokseumawe, kemudian penggugat diajak menjadi nasabah PT. Bank Pundi Indonesia cabang Lhokseumawe. Akhirnya atas ajakan tersebut karena penggugat sebagai nasabah Bank Danamon penggugat mengalihkan kredit dari Bank Danamon Kepada PT. Bank Pundi Indonesia cabang Lhokseumawe (take over) atau diambil alih.

Pada tanggal 15 November 2011 Penggugat menanda tangani perjanjian Kredit Nomor 002/F/812-P3/11/11 dengan PT. Bank Pundi Indonesia cabang Lhokseumawe, dengan fasilitas kerdit Rp. 50.000.000,00 (lima puluh juta rupiah), kemudian memberikan pinjaman lagi kepada Penggugat dengan tanpa anggunan pada tanggal 15 November 2011 sebesar Rp. 50.000.000,00 (lima puluh juta rupiah) jumlahnya Rp. 100.000.000,00 (seratus juta rupiah). Akibat besarnya kewajiban membayar pinjaman penggugat pada PT. Bank Pundi Indonesia cabang Lhokseumawe, maka usaha penggugat menjadi macet. Karena penggugat tidak sanggup membayar lagi kredit, akhirnya PT. Bank Pundi Indonesia cabang Lhokseumawe melelang/menjual lelang anggunan dalam perjanjian.

Atas alasan-alasan tersebut penggugat menggugat PT. Bank Pundi Indonesia cabang Lhokseumawe. Alasan dalil penyalahgunaan keadaan (misbruik van omstandigheden), yang disebutkan pada bagian konvensi Putusan 2039 K/Pdt/2014, adapun isi dalilnya yaitu: 
Bahwa sebagaimana ditegaskan dalam Pasal 1321 dan Pasal 1449, bahwa cacat perjanjian atau cacat kehendak terjadi karena kesalahan/penyesatan, penipuan, dan paksaan, meskipun Kitab Undang-undang Hukum Acara Perdata (BW) tidak mengatur secara detail terkait "Penyalahgunaan Kehendak atau yang sering disebut dengan misbruik van omstadigheden. Namun, penyalahgunaan keadaan sebagai salah satu syarat berkembangnya cacat kehendak dalam perjanjian, merupakan suatu doktrin yang muncul akibat berkembangnya beberapa peristiwa hukum dalam hukum kontrak.

Penyalahgunaan keadaan terjadi ketika seseorang mengetahui atau seharusnya memahami bahwa pihak lain karena keadaan khusus seperti keadaan darurat, ketergantungan, ketidakmampuan untuk berpikir untuk waktu yang lama, keadaan mental yang tidak normal atau kurangnya pengalaman tergerak untuk mengambil tindakan hukum meskipun dia tahu atau seharusnya mengerti bahwa dia harus benar-benar mencegahnya.

Bahwa, dalam kasus a quo penyalahgunaan kedaan terjadi karena dua hal, yaitu penyalahgunaan karena keunggulan ekonomi (economische overwicht). dan karena adanya manfaat psikologis (geestelijke overwich), dan syarat untuk memperoleh manfaat ekonomi harus memenuhi beberapa hal antara lain salah satu pihak yang membuat perjanjian lebih unggul dalam bidang ekonomi dari pada pihak lainnya, pihak lain terpaksa membuat perjanjian. Sedangkan penyalahgunaan kedaan karena keunggulan keunggulan psikologis (geestelijke overwicht), syaratnya antara lain adanya ketergantungan dari pihak lemah yang disalahgunakan oleh pihak yang mempunyai keunggulan psikologis, Adanya keunggulan psikologis luar biasa antara pihak yang satu dengan pihak yang lain.

Terkait perkara penyalahgunaan keadaan, berdasarkan hasil wawancara yang telah dilakukan dengan salah seorang hakim pada pengadilan Negeri Kelas 1B Lhokseumawe, dalam pandangan majelis hakim, hakim dalam mengadili suatu perkara, terlebih dahulu harus menentukan benar tidaknya peristiwa yang dihadirkan kepadanya. Setelah berhasil menentukan acara, hakim kemudian harus memenuhi persyaratan acara. Setelah itu hakim harus menentukan hukum apa yang akan digunakan untuk menyelesaikan sengketa yang bersangkutan. Disini kemudian hakim harus menemukan hukum, dalam menemukan hukum jika tidak ada aturan hukum yang mengatur secara spesifik, maka majelis hakim merujuk kepada beberapa sumber hukum peraturan perundang-undangan dan yurisprudensi. Salah satunya dalam hal menyelesaikan perkara penyalahgunaan kedaan.

Pertimbangan bagi hakim pada pengadilan Negeri Kelas 1B Lhokseumawe seperti putusan yang sudah dipaparkan di atas, hakim menerapkan tolok ukur dalam menentukan adanya penyalahgunaan keadaan ini, yaitu penyalahgunaan keunggulan ekonomis dan penyalahgunaan keunggulan kejiwaan.

Selanjutnya dalam menjalankan tugasnya hakim tidak selalu terpaku terhadap Undang-Undang atau suatu perjanjian (formal legalistik), tetapi senantiasa menyelaraskan hukum formal dengan nilai keadilan yang hidup di dalam masyarakat. Pasal 28 ayat (1) Undang-undang No. 4 Tahun 2004 Tentang Kekuasaan Kehakiman menyebutkan bahwa "hakim wajib menggali, mengikuti dan memahami nilai-nilai hukum dan rasa keadilan yang hidup dalam masyarakat". Dalam arti bahwa karena di dalam masyarakat masih terdapat hukum yang tidak tertulis dengan nilai-nilai hukum yang tetap dijunjung tinggi, 
maka hakim mampu mengenal dan memahami hukum tersebut sehingga dapat memberikan putusan yang sesuai dengan rasa keadilan masyarakat.

Selanjutnya dalam menjalankan tugasnya hakim tidak selalu terpaku terhadap Undang-Undang atau suatu perjanjian (formal legalistik), tetapi senantiasa menyelaraskan hukum formal dengan nilai keadilan yang hidup di dalam masyarakat. Pasal 28 ayat (1) Undang-Undang No. 4 Tahun 2004 Tentang Kekuasaan Kehakiman menyebutkan bahwa "hakim wajib menggali, mengikuti dan memahami nilai-nilai hukum dan rasa keadilan yang hidup dalam masyarakat". Dalam arti bahwa karena di dalam masyarakat masih terdapat hukum yang tidak tertulis dengan nilai-nilai hukum yang tetap dijunjung tinggi, maka hakim mampu mengenal dan memahami hukum tersebut sehingga dapat memberikan putusan yang sesuai dengan rasa keadilan masyarakat.

\section{KESIMPULAN}

Berdasarkan pemahaman yang telah diuraikan diatas, maka penulis dapat menarik kesimpulan:

1. Pengaturan penyalahgunaan keadaan dalam perjanjian kredit bank. Ajaran keadaan belum diatur secara tegas dalam KUHPerdata. Namun, dalam praktinya, penyalahgunaan keadaan telah dijadikan sebagai alasan untuk membatalkan suatu perjanjian atau digunakan sebagai alasan untuk menjelaskan suatu perjanjian. Dan ajaran penyalahgunaan keadaan di Indonesia semakin berkembang dan didukung oleh beberapa putusan hakim.

2. Pertimbangan hakim terhadap penyalahgunaan keadaan dalam perjanjian kredit bank dalam Putusan Nomor 2039 K/Pdt/2014 hakim dalam memutuskan perkara penyalahgunaan keadaan pada dasarnya didasarkan pada Economicdures (perekonomian) dan situasi (keuntungan ekonomi) adalah dua hal yang berbeda, tetapi ketika dihadapkan pada kasus yang cukup pelik, keduanya benar-benar kabur dan sulit ditemukan perbedaannya. Kedua hal tersebut merupakan perkembangan baru dalam hukum kontrak, seiring dengan terus berkembangnya bisnis yang kemudian melahirkan bentuk-bentuk standar kontrak. Untuk melindungi pihak yang dirugikan dalam suatu kontrak, maka dalil yang digunakan adalah Pasal 1320 BW, Pasal ini merupakan jelmaan dari cacat kehendak.

\section{DAFTAR PUSTAKA}

Ahmad Rifai, Temuan Hukum Hakim dalam Perspektif Hukum Progresif, Jakarta, Sinar Grafika, 2010.

Amiruddin, Pengantar Metode Penelitian Hukum, Raja Grapindo Persada, Jakarta, 2012.

Burhan Bugin, Metode Penelitian Kualitatif tentang Aktualisasi Metode Logika Menuju Ragam Variasi Kontemporer, Rajawali Pers, Jakarta, 2001.

CST Kansil, dkk, Dictionary of Legal Terms, Jalan Permata Aksara, Jakarta, 2009.

[Program Studi S1 Hukum Universitas Malikussaleh, Pedoman Pembelajaran, Tahun Pelajaran 2013/2014.

H. Salim H.S, Pengembangan Teori dalam Ilmu Hukum, Rajagrafindo Persada, Jakarta, 2010

H.B. Sutopo, Metodologi Penelitian Hukum Kualitatif Bagian II, UNS Press, Surakarta, 1998.

Haris hamid, Hukum Perlindungan Konsumen, Media Hukum, Makassar, 2017. 
Henry P. Panggabean, Penyalahgunaan Keadaan (Misbruik Van Omstandigheden) sebagai (Baru) Alasan Pembatalan Perjanjian (Berbagai Perkembangan Hukum di Belanda), Liberty, Yogyakarta, 1992.

Herlien Budiono, Kumpulan Tulisan Hukum Perdata di Bidang Notaris, Citra Aditya Bakti, Bandung, 2007.

Kees Bertens, Sejarah Filsafat Yunani, Kanisius, Yogyakarta, 1999.

Lexy J. Moleong, Penelitian Kualitatif, Pemuda Rosdakarya, Jakarta, 2007.

M. Kusnardi dan Harmaily Ibrahim, Pengantar Hukum Tata Negara, FH-UI, Jakarta, 1986.

Mertokusumo Soedikno, Hukum Acara Perdata Indonesia, Liberty, Yogyakarta, 2002.

Miriam Budiarto, Berbagai Pemikiran tentang Kekuasaan dan Kewenangan, Sinar Harapan, Jakarta, 1991.

Mohammad Jamin, Kebebasan Hakim dan Rasa Keadilan, Pelita, Jakarta, 1989.

Mukti Arto, Praktik Perkara Perdata di Pengadilan Agama, Cetakan 5, Perpustakaan Mahasiswa, Yogyakarta, 2004.

Nanda Agung Dewantara, Isu Kebebasan Hakim dalam Menangani Perkara Pidana, Aksara Persada Indonesia, Jakarta, 1987.

Riduan Syahrani, Ringkasan Esensi Ilmu Hukum, Citra Aditya Bakti, Bandung, 1999.

Shidarta, Moralitas Profesi Hukum Sebuah Kerangka Persembahan untuk Berpikir, Revika Aditama, Bandung, 2006.

Soerjono. Soekanto, Sosiologi Sebuah Pengantar, Raja Grafindo Persada, Jakarta, 2012.

Suharmi Arikunto, Prosedur Penelitian Suatu Pendekatan Praktis, Rineka Cipta, Jakarta, 2002.

Sudikno Mertokusumo. Mengetahui Hukum Pendahuluan. Yogyakarta, Kemerdekaan, 1996.

Sunarto, Peran Aktif Hakim dalam Perkara Perdata, Edisi Pertama, Kencana, Jakarta, 2014.

Zainuddin Ali, Metode Penelitian Hukum, Sinar Grafika, Jakarta, 2009.

Endro Martono. Penyalahgunaan Keadaan Sebagai Dasar Pembatalan Perjanjian. Jurnal Yustisia Merdeka: Jurnal Ilmiah Hukum. Jilid 2 Nomor 2.

Enrico Simanjuntak, Peran Ilmu Hukum dalam Sistem Hukum Indonesia, Jurnal Fakultas Hukum Universitas Indonesia, Jakarta, Vol. 16, No. 1, Maret 2019.

Nur Iftitah Isnantiana, Penalaran Hukum Hakim dalam Pengambilan Keputusan di Pengadilan, Jurnal Pemikiran Islam, Volume XVIII, No. 2 Juni 2017, Universitas Muhammadiyah Purwokerto.

Muhammad Arifin, Penyalahgunaan Keadaan Sebagai Faktor Pembatas Kebebasan Berkontrak, Jurnal Ilmu Hukum, Universitas Muhammadiyah Sumatera Utara, Vol. 14, No. 2, September 2011.

Yenni Triana, Pemahaman Itikad Baik dan Penyalahgunaan Keadaan dalam Kontrak, Jurnal Fakultas Hukum Universitas Lancang Kuning, 2011.

Subliyanto, Subjek Penelitian dan Responden Penelitian, Diakses Dari <http://www.Google weblight.com>, Diakses 19 Juni 2019.

Fatmah Paparang, Misbruik Van Omstandigheden dalam Pengembangan Hukum Kontrak, Jurnal Fakultas Hukum Universitas Sam Ratulangi, Sulawesi Utara, Vol. 22, No. 6 Juli 2016.

Utiyafina Mardhati Hazhin, Penyalahgunaan Keadaan dalam Perjanjian Asuransi di Telemarketing, Jurnal Fakultas Hukum Universitas Surabaya, Surabaya, Vol. 41, No. 2, Agustus 2019. 